\title{
Research
}

\section{The Role of Economic and Social Factors Driving Predator Control in Small-Game Estates in Central Spain}

\author{
Miguel Delibes-Mateos $^{1}$, Silvia Díaz-Fernández ${ }^{1}$, Pablo Ferreras ${ }^{1}$, Javier Viñuela ${ }^{1}$ and Beatriz Arroyo ${ }^{1}$
}

\begin{abstract}
One of the most important human-wildlife conflicts in the world is that where predators are involved. Predators may compete with us for the same resources, such as game species. As a consequence, predators have been frequently controlled by game managers, which has negatively affected many predator populations worldwide. The understanding of human-wildlife conflicts requires a multidisplicinary framework that is rarely considered. We aim to evaluate the attitudes and behavior of game managers with regard to predator management in central Spain, as well as to explore factors that lead to these attitudes and behavior. Data were gathered through face to face interviews with game managers from 59 small-game hunting estates within central Spain. Predator control was employed in $90 \%$ of the estates, but control intensity was very variable among estates. Economic interests and perceptions about predators apparently influenced variation in control intensity. The main methods employed were cage-traps and shooting, but some illegal practices (e.g., leg-hold traps or snares without stopping devices) were also admittedly used for carnivores. Most managers considered that efficacy of legal methods for control of foxes (Vulpes vulpes) was very limited. Overall, nonselective methods, such as some types of snares, were more frequently employed in commercial than in noncommercial estates. Most managers believed that predators had an important effect on prey, and therefore that not doing it would lead to smaller hunting bags. Only managers from commercial hunting estates used stronger discourses such as that hunting would be impossible without carrying out predator control, which suggests that their tolerance for predators was lower than that of managers whose main motivation was not economic. Most managers considered that predator control was effective to reduce the number of predators, but only in the short term. Therefore, they highlighted the need of maintaining predator control every year. Our results highlight the important role that both social and economic factors (even stronger than ecological factors) play driving predator control, and therefore the need of incorporating these factors when making decisions to mitigate the human-predator conflict.
\end{abstract}

Key Words: attitudes towards predators; game management; human-wildlife conflicts; perceptions; Pica pica; Vulpes vulpes

\section{INTRODUCTION}

We humans exploit an increasingly higher proportion of the world's resources to support our own kind. This implies that we often and increasingly come into conflict with wildlife. Importantly, conflict between humans and wildlife is one of the most critical threats facing many wildlife species today, and it is therefore considered a hot topic in conservation (Macdonald and Service 2007). In this regard, perhaps the most important human-wildlife conflicts in the world are those where predators are involved (Woodroffe et al. 2005). Predators may eat our livestock, may compete with us as hunters for wild prey populations, and may even injure and kill us (e.g., Valkama et al. 2005, Kaartinen et al. 2009, Kushnir et al. 2010). Where predators cause, or are perceived to cause, serious damage to human livelihood, a common response has been to kill them (Woodroffe et al. 2005). In fact, people have been subjecting predators to control for centuries if not millennia (Reynolds and Tapper 1996). For example, as early as AD 800 the Emperor Charlemagne founded an order of knights, called the Louveterie, for killing wolves (Canis lupus; Boitani 1995). This persecution of predators has led to the extinction of several species and caused massive contractions of the geographic ranges of many others (e.g., Langley and Yalden 1977, Whitfield et al. 2003). Predator control, when illegally implemented but even that carried out legally, still causes at present the decline of species of conservation concern in many areas worldwide. For example, nonscience based management designed to reduce grizzly bear (Ursus arctos) abundance aimed at increasing ungulate numbers available for hunters seems to be jeopardizing portions of the largest and most intact population of grizzly bears in North America (Alaska; Miller et al. 2011). On the other hand, many predators are considered of conservation concern or are flagship species (Sergio et al. 2008), and predator control is considered unethical by some sectors of society. However, predator control has become a tool frequently used by conservationists when predation constitutes a major problem for the conservation of endangered prey species (Smith et al. 2010). In fact, some scientists have claimed that preventing an undesirable increase in density of some opportunistic and anthropophilic predator species is one of the main contributions of hunting management to nature conservation (Tapper 1999).

Although a wide range of technical approaches exist for damage limitation (reviewed in Dickman 2010), complete, long-term conflict resolution is rare (e.g., Webber et al. 2007). This is mainly because causes of conflict are often complex 
and some are rarely considered in conflict studies. Thus, although human-predator conflicts are generally embedded into an ecological, economic, and social context (Fig.1; White et al. 2009), most studies performed to date focus only on ecological aspects (e.g., Keech et al. 2011). For example, there have been many ecological studies aiming to assess predator control effectiveness in reducing livestock or game bag losses; these have produced various results, suggesting that predator control effectiveness is highly context dependent (reviewed in Smith et al. 2010). In contrast, social aspects driving humanpredator conflict, and hence predator control, have traditionally received little attention in the literature, and this has mainly concentrated on attitudes by general public (Messmer et al. 1999). Only recently, the attitudes of people affected by predators have been considered in predator control studies. For instance, recent studies have found that lion (Panthera leo) killing in Kenya is shaped, to a great extent, by Maasai people's perception of livestock depredation (Hazzah et al. 2009). Nevertheless, most of these studies have addressed conflict caused by livestock loss (e.g., Dar et al. 2009, Hemson et al. 2009), whereas only a few of them have investigated conflict derived from the depredation of game species (but see Marker et al. 2003). Similarly, economic factors related to predator control in hunting contexts have been rarely considered in the literature, although it is known that the attitude of stakeholders towards predators may depend on their economic interests (e.g., Hazzah et al. 2009).

In summary, the understanding of biodiversity conflicts requires a multidisciplinary framework that integrates social, economic, and ecological factors and their interplay (White et al. 2009). We aim to evaluate the attitudes and behavior of game managers with regard to predator management in smallgame estates in central Spain, as well as to explore the social, economic and ecological factors and their interplay that lead to these attitudes and behavior (Fig. 1). Our specific goals included: 1) to evaluate quantitatively the extent of the implementation of predator control in central Spain, and to assess the frequency of use of different predator control methods; 2) to explore social factors driving predator control activities by evaluating the stated reasons that lead game managers to control predators, as well as their perception of the efficacy of this management practice; 3) to assess the interplay between social and economic factors through the investigation of whether managers' perceptions regarding predator control vary according to the potential economic loss at stake by comparing noncommercial and commercial hunting estates; 4) to explore the relationship between social, ecological, and economic factors and their interplay and the practices carried out by game managers; e.g., whether predator control intensity or the methods used varied according to game managers perceptions and/or to the type of hunting estate (commercial or not).
Fig. 1. The diagram shows examples of ecological, economic and social factors relevant to the conflict between human and predators in the Iberian Peninsula (inspired by White et al. 2009), and their influence in the practices carried out by game managers. Note that the actors' behaviour as well as the consequences are extreme examples.

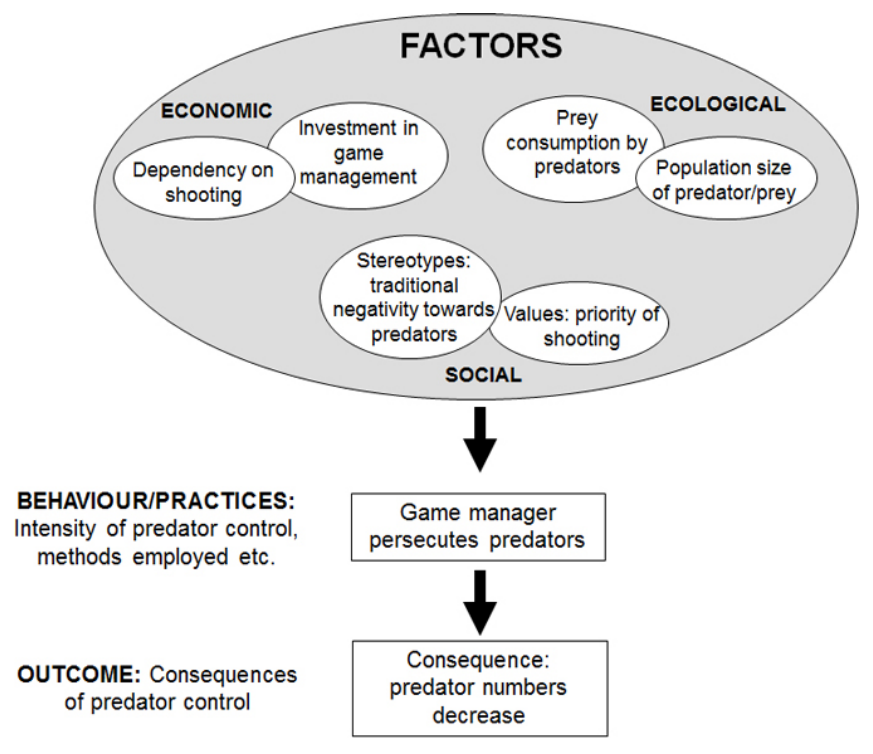

\section{METHODS}

\section{Context and study area}

Central Spain constitutes a very good place to investigate conflicts between hunting and predators. On the one hand, hunting is a very important socio-economic activity in this region, where $>80 \%$ of the territory is covered by hunting estates (Ríos-Saldaña 2010). Practically all these estates (99\%) are managed privately, whereas only a few are managed by the government agency. Either an individual game manager or the board of a hunting society is in charge of management decision making in each estate. Game management, which usually includes predator control, takes place in most hunting estates in central Spain (Virgós and Travaini 2005, DelibesMateos et al. 2008, Ríos-Saldaña 2010). On the other hand, Spain harbors one of the richest predator communities within Europe, which includes several raptors and carnivores of conservation concern, such as the endemic Iberian lynx (Lynx pardinus) and Spanish imperial eagle (Aquila adalberti), which are considered among the most endangered predators in the world (Ferrer and Negro 2004).

Our study was conducted in small-game estates mainly devoted to the hunt of the red-legged partridge (Alectoris rufa). 
This is the most important gamebird in Spain both socially and economically, and like other ground-nesting birds, may be subject to high predation rates (Herranz 2001), although it is not clear whether predation is the main driver of its demography (Casas and J. Viñuela 2010, Blanco-Aguiar et al. 2012, Mateo-Moriones et al. 2012). Wild red-legged partridge populations have strongly declined during last decades, which has promoted releases of millions of farm-bred birds that may be highly susceptible to predation (Alonso et al. 2005).

In central Spain, four predator species are currently listed as small-game species: the red fox (Vulpes vulpes), the jackdaw (Corvus monedula), the magpie (Pica pica) and the carrion crow (Corvus corone). This means that hunters are allowed to shoot these animals during the regular hunting season, which lasts from October to February. According to the hunting laws, the control of these predators using methods other than shooting (i.e., snares with stopping devices and cage traps) and/or outside the regular hunting season is only exceptionally permitted and can only be carried out after receiving a legal permit from the regional administration. In practice, more than $85 \%$ of hunting estates consider asking for that special permit in their five-year hunting management plans (Ríos-Saldaña 2010), although it has not been evaluated whether they use it every year or only occasionally. In addition, game managers can also request special permits to eliminate feral cats (Felis catus) and dogs (Canis lupus familiaris). In general, foxes and magpies are the main species legally subjected to control by game managers in central Spain (Ríos-Saldaña 2010). The control of nongame predator species and the use of other methods (e.g., poisoning) are strictly prohibited according to the legislation (although sometimes there are exceptional permits to control other species, such as some rodents). However, illegal predator killing by hunters has been frequently documented in central-southern Spain (Villafuerte et al. 1998, Márquez et al. 2012), and indeed it is considered among the main causes explaining the decline of some endangered predators. For example, the analysis of 267 records of nonnatural mortality of the Spanish imperial eagle over a 16-yr period (1989-2004) showed that near $40 \%$ of the deaths were caused by predator control, and almost all of them occurred in central-southern Spain (González et al. 2007).

In central Spain there are three different types of small-game hunting estates according to their profitability aims: 1) noncommercial estates, where the stated aim is leisure (i.e., to provide access to game to local hunters or a group of friends that rent the hunting rights for a time period);2) commercial estates, where the stated aim is to obtain economic benefit from the hunting rights; 3 ) intensive estates, which are a special type of commercial estate in which the release of farm-reared partridges is legally permitted without numerical limits throughout the year. Intensive estates are qualitatively different from other commercial estates: partridge annual bags there are much higher, and are linearly related to the number of released partridges (thus indicating that hunting there is not based on wild stock, but on game releases; Díaz-Fernández et al. 2012a); numbers released per year are approximately 1000 times higher than in other commercial estates (Arroyo et al. 2012), and the intensity of most management practices (including predator control) is also much higher than in other commercial estates (Arroyo et al. 2012). In addition, a recent study has shown that the total expenses are much higher in intensive estates (range 9298-66,273 €/ $\mathrm{km}^{2}$ ) than in nonintensive estates (175-6270 €/ $/ \mathrm{km}^{2}$; Díaz-Fernández et al. $2012 b$ ). Interestingly, one of the main expenses of these estates is the salary of the gamekeepers (on average $22.5 \%$ of the total expenses; Díaz-Fernández et al. 2012b), who typically undertake predator control. Intensive estates also obtain much greater profits per $\mathrm{km}^{2}$ than others (range 5264 to $67,123 € /$ $\mathrm{km}^{2}$ vs -2472 to $512 € / \mathrm{km}^{2}$, Díaz-Fernández et al. 2012b).

\section{Data collection and analysis}

Our study was conducted in 59 partridge hunting estates within central Spain, which cover a total surface of 208,648 ha (Arroyo et al. 2012). Overall, the whole range of management situations, from unmanaged to very intensively managed, was surveyed. Predator control data were gathered through face to face in depth interviews with game managers, conducted in $2005(n=26), 2008(n=10)$ and $2009(n=23)$. Many of the managers were selected from a data base of hunting estates that was provided to us by two hunting associations with large influence areas; among these were all the managers of the intensive estates. In addition, we contacted some managers through hunters who had previously collaborated with our institute. In these cases, we identified initial interviewees as people responsible of hunting associations or individual hunters for participating in a different project, and these provided contact information for subsequent participants (i.e., a snowballing procedure; Oñate and Peco 2005, Schüttler et al. 2011).

The interviews were between two and three hours long, and were always conducted by the same person (Silvia DíazFernández). The interview had four main sections, dealing with 1) general characteristics of the hunting estate (size, ownership, other land uses such as agriculture, livestock, etc.); 2) hunting styles and pressure; 3 ) game management practices (gamekeepers, predator control, habitat management, disease treatments, and release of farm-reared partridges); 4) economic information (expenses, price asked for hunting, etc.). In a recent study, Arroyo et al. (2012) provided a global description of the characteristics of the hunting estates (e.g., their size, main land uses, etc.), as well as a general overview of the management carried out in these estates and the hunting styles and pressure, in relation to their profitability aims (i.e., comparing commercial and noncommercial estates). In the present manuscript, we specifically focus on the practices and perceptions regarding predator control. To do so, we analyzed in depth the specific section of the interviews dealing with this 
Table 1. Themes covered in the interview and the specific questions asked to game managers. The number of respondents for each specific question in noncommercial, commercial, and intensive hunting estates is shown.

\begin{tabular}{cccc}
\hline \hline Question & \multicolumn{2}{c}{ Number of respondents } \\
\cline { 2 - 4 } & $\begin{array}{c}\text { Noncommercial } \\
\text { estates }\end{array}$ & $\begin{array}{c}\text { Commercial } \\
\text { estates }\end{array}$ & Intensive estates \\
\hline
\end{tabular}

Predator control use

Do you carry out any type of predator control?

14

Predator species subjected to control

Are magpies controlled in your estate?

How many magpies are removed annually in your estate?

Are red foxes controlled in your estate?

How many foxes are removed annually in your

estate?

Predator control methods

Do you use shooting to control magpies?

Do you use cage traps to remove magpies?

Do you use shooting to control foxes?

Do you use cage traps to capture foxes?

Do you use snares with stopping devices to remove

foxes?

Do you use snares without stopping devices to remove foxes?

Do you use leg-hold traps to capture foxes?

Do you hunt foxes in warrens using terrier dogs?

Do you use poison to control predators?

Effect of predators on small game

Do you think predators negatively affect small-game species?

Why do you think predators negatively affect small game?

Which are, in your opinion, the main predators

affecting small game?

Reasons that lead to control predators

Why do you use predator control?

Effectiveness of predator control

In your opinion, is predator control effective to reduce the number of predators?
13

12

14

14

$\begin{array}{ll}14 & 33 \\ 14 & 33 \\ 14 & 33 \\ 14 & 33 \\ 14 & 33 \\ & \\ 14 & 33 \\ 14 & 33 \\ 14 & 33 \\ 13 & 3\end{array}$

12

10

13

10

8
33

33

33

33

33

33

33

30

12

8

30

7

8

25

35

55

55

55

55

55

55

55

50

32

26

50

6
59

57

53

58

56

55

21 topic. Not all the managers responded fully to all the questions related to this, which means that sample size varied among analyses (Table 1).

We provided confidentiality and anonymity to managers to positively influence their willingness to share information on predator control, which is usually viewed as a highly controversial issue. In addition, we tried to reduce the potential effect of social desirability bias (where the participants wish to appear socially or morally worthy; Maccoby and Maccoby 1954) as a consequence of the interviewer's identity (natural scientist) through adopting a neutral position during the interviews (Schüttler et al. 2011). Because familiarity and aid builds trust, we did not ask about predator conflict or other sensitive topics during the initial steps of the interview, which were used to inquiry about the general characteristics of the hunting estates. Once the manager became familiarized with the interviewer, he/she was questioned in depth about predator control issues. This helped us to gather data with greater confidence in its accuracy. To foster a comfortable, nonintimidating exchange between the interviewer and 
respondents, the interviews were conducted in an informal, conversational manner (Kvale 1996). A semistructured approach was adopted, combining closed questions and the flexibility of more open questions targeted at capturing the game managers' perceptions (see an example of this approach in Oñate and Peco 2005).

In particular, and in regard to predators and their control, we asked whether or not this practice was carried out in each estate, as well as how many red foxes and magpies were killed in each estate during the year prior to the interview (which we report per $\mathrm{km}^{2}$ for comparisons; Table 1). In addition, we asked whether or not several legal or illegal predator control methods were used (Table 1). These included, among the legal, shooting and cage traps for magpies (Díaz-Ruíz et al. 2010), and shooting, snares with stopping devices, cage traps, and hunting in warrens using terrier dogs for carnivores (Herranz 2001, Ferreras 2009, Duarte et al. 2012, see also Heydon and Reynolds 2000). Among the illegal methods considered, we asked about poison, snares without stopping devices, and leghold traps for carnivores.

Regarding perceptions, we asked game managers whether they thought that predators affected game populations or not, the reasons supporting their beliefs, and which predator species they thought mostly affected game species (Table 1). In addition, we questioned them about their main reasons for carrying out predator control, and whether predator control was considered effective or not to reduce the number of predators. All these were open questions, and hence very different answers were obtained. We adopted a qualitative design to categorize answers for analyses. Such methodology, which is increasingly applied to explore environmental phenomena in depth (e.g., Fischer and Young 2007), allows perceptions to emerge that, to some extent, go beyond our own sets of beliefs (Schüttler et al. 2011). This approach (described by Mayring 2000, see also an example in Schüttler et al. 2011) is theory driven following analytical rules (generalization and reduction of paraphrases), and is a descriptive method to interpret systematically textual data. Step by step, we deduced categories from the text material, revised them and reduced them to main categories (inductive category development, Mayring 2000).

Since game management intensity (including intensity of fox and magpie control) varies with the profitability aim of the hunting estate (see above; Arroyo et al. 2012), we suspected that other aspects associated with predator control may also vary between different types of estates. We thus assessed, for example, the differences in the perception of managers regarding the effect of predators on prey populations and/or the effectiveness of predator control between noncommercial $(\mathrm{n}=14)$, commercial $(\mathrm{n}=37)$ and intensive estates $(\mathrm{n}=8)$. Similarly, we tested whether control methods that require a great effort and specialized personnel (i.e., gamekeepers), such as snares, were more frequently employed in intensive estates, where more gamekeepers are employed on average than in other estates (Arroyo et al. 2012).

\section{RESULTS}

\section{Predator control intensity and methods employed}

Predator control was used as a management tool in $~ 90 \%$ of the hunting estates $(n=59)$, including all of the intensive estates. Only six hunting estates reported not using it. However, among these six, foxes and magpies were harvested during the regular hunting season in two estates (for control purposes, not as valued game). In another one, predators were not controlled because managers did not receive the official permit required to carry out this activity (although it was applied for). Thus, only in three estates the game manager had no intention of performing predator control. Red foxes were controlled in 46 hunting estates ( $>85 \%$ of the hunting estates that employed predator control; $\mathrm{n}=53$ ), whereas magpies were controlled in 44 estates (>80\% of the hunting estates that employed predator control; $\mathrm{n}=53$ ). In 37 estates, both foxes and magpies were removed. The number of foxes killed annually per estate ranged from 0.01 to 25.12 foxes $/ \mathrm{km}^{2}$ (mean $=1.93 ; \mathrm{SE}=0.56$; median $=1.03$; lower quartile $=0.43$; upper quartile $=1.97 ; \mathrm{n}=45$ ). In the case of magpies, the number of birds killed annually per estate varied between 0.21 and 113.44 magpies $/ \mathrm{km}^{2}($ mean $=20.22 ; \mathrm{SE}=3.57 ;$ median $=$ 13.98; lower quartile $=9.06$; upper quartile $=22.61 ; \mathrm{n}=40$ ).

The proportion of hunting estates that used different predator control methods is shown in Figure 2. Overall, the most frequently employed methods to capture magpies were cage traps and shooting, the latter being also the most frequently one used to kill foxes. Interestingly, a few managers reported using illegal methods such as leg-hold traps $(5.35 \% ; n=56)$ or snares without stopping device $(10.71 \% ; \mathrm{n}=56)$. No manager stated that they used poison, but one specified that "they had not used it in the last 4-5 yrs", implying that they used it before (even if it was also illegal at the beginning of the 2000s). The frequency of hunting estates that used snares, which are potentially nonselective capture devices (Duarte et al. 2012), increased from noncommercial $(21.24 \% ; n=14)$, to commercial $(44.11 \% ; \mathrm{n}=34)$, and to intensive game estates $(75 \% ; n=8)$. In contrast, the frequency of hunting estates in which foxes were killed in their warrens using terrier dogs, a very selective control method, was much higher in noncommercial hunting estates $(71.42 \% ; \mathrm{n}=14)$ than in commercial and intensive hunting estates $(26.47 \% ; \mathrm{n}=34$ and $25 \% ; \mathrm{n}=8$, respectively).

\section{Perceptions about predators and reasons for carrying out predator control}

Most managers $(87.5 \% ; \mathrm{n}=32)$ considered that predators negatively affected small-game species in their hunting estates. When asked about the predators most affecting game, 
most managers (39 out of 50) mentioned protected species: rodents $(n=4)$, reptiles $(n=7)$, protected carnivores such as mustelids or Egyptian mongoose (Herpestes ichneumon; $\mathrm{n}=$ $13)$, raptors $(\mathrm{n}=14)$ or other birds (white stork, Ciconia cinocia, or Eurasian jay, Garrulus glandarius; $n=4)$. The perception of protected species among the most damaging to game was equally frequent among managers of commercial or noncommercial estates $(76 \%, \mathrm{n}=37$ vs $77 \%, \mathrm{n}=13$, respectively). Only four managers thought that there was no (or not significant) effect of predators on small game, and two of them believed that this was because they had controlled predators very efficiently in the past. According to their answers, their perception of the effect of predators on game was based mostly on their frequent observation of predators within the estate (Table 2). The belief of predators being too abundant was more common in noncommercial hunting estates $(70 \%$ of the managers of these estates used this argument; $\mathrm{n}=10)$ and in commercial hunting estates $(62.5 \%$; $\mathrm{n}=8)$, than in intensive hunting estates $(25 \% ; \mathrm{n}=8)$. Observation of predation events (i.e., having found smallgame animals killed by predators, or depredated nests) was also a frequent argument among managers (Table 2). This argument was more common in commercial and intensive hunting estates $(50 \% ; \mathrm{n}=8$ in both commercial and intensive hunting estates) than in noncommercial ones $(20 \% ; n=10)$. Interestingly, only one manager specifically declared to believe that predators affected game because he had directly observed an increase in small-game animals when predators were controlled (Table 2).

Fig. 2. Proportion of estates (in black) that used different methods for controlling predators

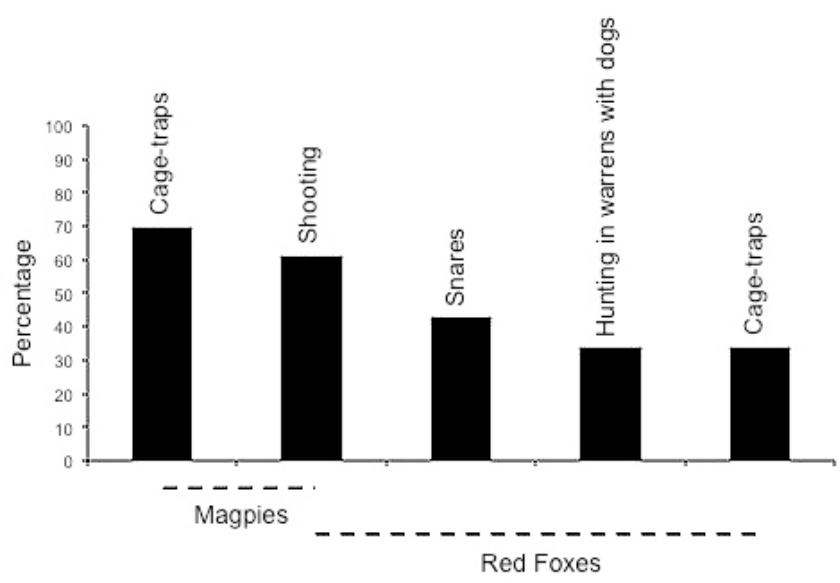

Most managers stated that they performed predator control because not doing so would lead to smaller hunting bags, or that predators interfered with their hunting objectives (Table 3). Some of them even considered that hunting would not be possible if predators were not removed; this stronger argument was exclusively given by managers from commercial $(57 \%$; $\mathrm{n}=7)$ and intensive hunting estates $(37 \% ; \mathrm{n}=8)$. Almost a quarter of the interviewed managers also said that they controlled predators to maintain an ecological equilibrium (Table 3). This argument was used by managers from intensive $(25 \% ; \mathrm{n}=8)$, commercial $(15 \% ; \mathrm{n}=7)$, and noncommercial estates $(30 \% ; n=10)$. Other arguments, such as aesthetic or traditional reasons, were occasionally given to explain why predators were removed (Table 3).

Although differences were not statistically significant (Kruskal-Wallis chi-squared $=1.64$, df $=2, P=0.43$ ), managers who considered that hunting would be impossible without carrying out predator control removed on average more foxes than those who thought that the main consequence of not performing predator control would be that partridges would be less abundant (and hence game bags would be smaller). In addition, the latter killed more foxes than those that thought that predator control did not affect their game bags (Fig. 3a). Although less markedly, this pattern was also observed in the case of magpies (Fig. 3b; Kruskal-Wallis chisquared $=1.23, \mathrm{df}=2, P=0.53$ ).

Fig. 3. Number of predators controlled, (a) fox, vulpes vulpes and (b) magpies, pica pica, by three types of game managers: 1) managers who believed that predator control doesn't affect hunting bags; 2) those who thought that more partridges are harvested when predators are controlled; 3) those who believed hunting would be impossible without predator control

a)

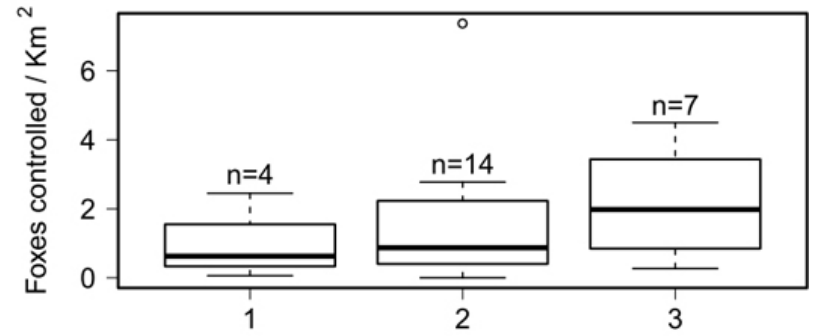

b)

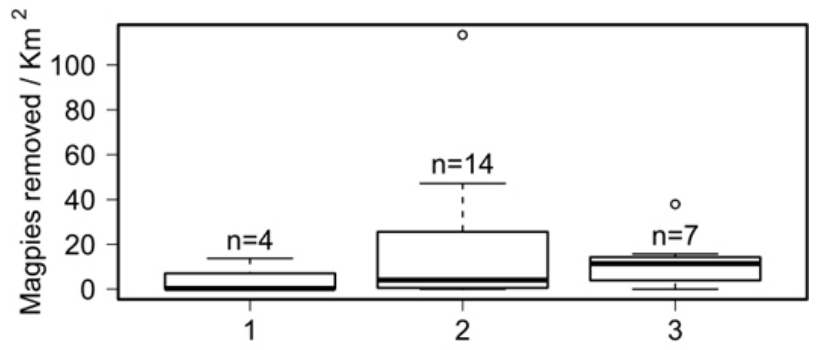


Table 2. Main arguments given by managers to support their belief that predators negatively affect small-game species; arguments revealed from 26 qualitative interviews. Note that some managers gave more than one argument.

\begin{tabular}{|c|c|c|}
\hline $\begin{array}{c}\text { Number of } \\
\text { managers }\end{array}$ & Argument & Sample quotes \\
\hline $14(53.84 \%)$ & Predators are too abundant & $\begin{array}{l}\text { "...predators are increasingly more abundant, especially foxes" } \\
\text { "There are many foxes and the abundance of other predators is increasing" } \\
\text { "There are many Egyptian mongooses and cats, which are the most harmful } \\
\text { predators, and which were not present some time ago" }\end{array}$ \\
\hline $9(34.61 \%)$ & Predators prey on animals and nests & $\begin{array}{l}\text { "...every year near } 15,000 \text { of the partridges that we release for hunting are } \\
\text { predated" } \\
\text { "We monitor in depth our hunting estates, and find carcasses of animals that } \\
\text { have been consumed by predators" } \\
\text { "Finding predated nests is very common in our estate" }\end{array}$ \\
\hline $4(15.38)$ & $\begin{array}{l}\text { Predators have to eat (and prey are } \\
\text { abundant) }\end{array}$ & $\begin{array}{l}\text { "There are many predators, and they have to eat every day" } \\
\text { "Farm-reared partridges constitute a good food source for predators" }\end{array}$ \\
\hline $2(8 \%)$ & Effect of predators from neighbor areas & $\begin{array}{l}\text { "There is a National Park close to our estate, and predators come from there to } \\
\text { prey on small-game animals" } \\
\text { "The abundance of small-game species on neighbouring hunting estates is very } \\
\text { low, and as a consequence predators living there are forced to move to our } \\
\text { estate" }\end{array}$ \\
\hline $1(4 \%)$ & $\begin{array}{l}\text { The density of small-game species is } \\
\text { lower when predators are not controlled }\end{array}$ & $\begin{array}{l}\text { "Some years ago, there was a high density of foxes, and the abundance of } \\
\text { small-game species was low. After controlling them, we have observed an } \\
\text { increase in small-game animals" }\end{array}$ \\
\hline
\end{tabular}

\section{Perceptions about efficacy of predator control}

Most managers considered that predator control was effective to reduce the number of predators $(>75 \% ; n=35)$. However, more than $50 \%$ thought that it was effective only in the short term. For example, a manager quoted: a reduction in the number of predators is noticed, but the following year they recover their original numbers, if predator control is not maintained. Therefore, game managers highlighted the need of maintaining the control of predators every year. A few managers stated that although predator control could be effective as a management tool, it was not efficient enough within their estates because there were too many protected predators or because it was not carried out in neighboring hunting estates. Only eight managers considered that predator control was not effective to reduce the number of predators. Two of them said that only currently illegal methods, such as poisoning and snares without stopping device, were effective. It was also mentioned that there was a need of controlling protected predators (i.e., mustelids) to make predator control really effective. In relation to the type of predator, it was frequently stated that predator control was effective in reducing the number of magpies; this was mentioned by seven respondents $(n=35)$. In contrast, the general view was that predator control was less useful (or even totally inefficient; this was answered by three managers) to control foxes.

\section{DISCUSSION}

Practices about predator control in small-game estates in central Spain

Predator control was performed to some degree in almost all of the studied small-game estates. Only in Castilla-La Mancha (the main part of our study region), 49,000 $\mathrm{km}^{2}$ are devoted to small game (Ríos-Saldaña 2010), which means that, according to our findings, predator control there would take place in $>44,000 \mathrm{~km}^{2}$. This surface substantially exceeds that covered in other better-studied human-predator conflicts within Europe; e.g., the surface of the land managed for red grouse (Lagopus lagopus scoticus) shooting in the British Uplands is approximately $7500 \mathrm{~km}^{2}$ (Thirgood et al. 2000).

The intensity of predator control (evaluated as numbers killed per $\mathrm{km}^{2}$ ) varied however strongly among hunting estates. The average levels of foxes killed reported here are of the same order as those reported in Great Britain (Macdonald and Johnson 1996, Heydon and Reynolds 2000). Surprisingly, the maximum number of reported foxes and magpies controlled in our study area considerably exceeds the highest published abundances of these species in the Iberian Peninsula (2.5 foxes $/ \mathrm{km}^{2}$ and 80 magpies $/ \mathrm{km}^{2}$; Gortázar 1997, Díaz-Ruíz et al. 2010, respectively). This may imply that predator removal in small-game management areas may favor immigration and 
Table 3. Main arguments given by managers for carrying out predator control; arguments revealed from 25 qualitative interviews. Note that some managers gave more than one argument.

\begin{tabular}{llc}
\hline \hline $\begin{array}{l}\text { Number of } \\
\text { managers }\end{array}$ & Argument & Sample Quotes \\
\hline
\end{tabular}

$21(84 \%) \quad$ Not doing so would negatively affect hunting bags

$\begin{array}{ll}\text { (A) } 7(28 \%) & \text { (A) Hunting would be impossible }\end{array}$

$\begin{array}{ll}\text { (B) } 14(56 \%) & \text { (B) Hunting bags would be scarcer }\end{array}$

$6(24 \%) \quad$ It is essential to maintain the ecological equilibrium

$4(16 \%)$
Others (Tradition, aesthetics, etc.)
(A) "If predators were not controlled, hunting could not be commercialized"

"otherwise, there would be no partridges"

"If predator control was not practiced, partridge populations would become extinct"

(B) "If we did not control predators, hunting bags would be smaller"

"We control predators to increase game species"

"Predator populations would increase substantially if we did not control predators"

"...to maintain the ecological equilibrium"

"Predators would increase a lot, as there are no superpredators"

"We control magpies for aesthetic reasons"

"...because it has been carried out since many years ago" recruitment of younger animals from adjacent areas, and therefore game estates with strong predator control can constitute predator population sinks (Robinson et al. 2008, Beja et al. 2009). An alternative explanation would be that gamekeepers may be under pressure to exaggerate the number of predators killed when reporting to managers (see an example in Heydon and Reynolds 2000). This pressure may arise because gamekeepers are employed by managers, who may believe that the best gamekeepers are those who kill more predators.

In any case, among-estate variation in the numbers of predators killed may reflect different predator abundances and/or different efforts made to capture predators (Heydon and Reynolds 2000). We did not have information about predator abundance, so we cannot evaluate the impact of this variable on explaining the numbers killed in each estate. However, our results suggest that it is also likely that observed values reflect different effort as well, which may relate to motivations or means. A previous study showed that more foxes and magpies are killed on average in commercial than noncommercial estates, and this is associated with the fact that more gamekeepers are employed in the former than in the latter (Arroyo et al. 2012). Therefore, having the means (i.e., more gamekeepers) may allow more intensive predator control. Additionally, we show in this study that managers' tolerance of predators may influence intensity of predator control (see below).
In terms of methods, there was a much wider variety of methods used for foxes than for magpies. Almost $70 \%$ of the studied hunting estates used cage traps to control magpies. This is not surprising since many managers believed that this constitutes an effective way to reduce the number of magpies (see results), and in fact it has been experimentally proven that these traps are very selective and that their efficiency is high during the breeding season (Díaz-Ruíz et al. 2010). Shooting was also commonly employed to kill both magpies and foxes, perhaps because it is a cheap method but also because it constitutes an additional hunting opportunity outside the hunting season. Other methods were much less frequently employed to control foxes, either because their perceived efficiency, as mentioned by several managers in our interviews, is very low (e.g., cage traps; Baker et al. 2001, Muñoz-Igualada et al. 2008), or because they require specific personnel (i.e., they are expensive), such as the use of snares. Interestingly, the use of several methods, such as leg-hold traps, that are currently forbidden by the European and Spanish laws was also mentioned. This could be explained by the fact that many managers believed that current legal methods to capture carnivores are inefficient. Finally, game managers from commercial estates (especially from intensive estates) more frequently used methods that are potentially less selective, such as snares (see Duarte et al. 2012). This may reflect the fact that they are more labor-intensive to use and that, as stated, this type of estate employs a higher number of gamekeepers (Arroyo et al. 2012) or differences in tolerance 
towards all predators between managers of commercial and those of noncommercial game estates (see below).

\section{Perceptions and economics driving predator control}

Removal of predators due to their perceived contribution to game or stock loss is a common characteristic of carnivore management all around the world and is well illustrated by the cases of the red fox on farmlands in the United Kingdom (Baker and Macdonald 2000) or Cheetahs (Acinonyx jubatus) on Namibian farmlands (Marker et al. 2003). In general, people base their perceptions and attitudes not only upon facts, but also upon a myriad of factors such as cultural norms, expectations, and beliefs (Dickman 2010). In this study, we noticed that although game managers perceive predators as very harmful for small game, this was rarely based on their observation of a lower abundance of small-game species when predators are not controlled (only one game manager had apparently experienced this; Table 2). In contrast, game manager perceptions towards predators were apparently based on their expectations (Table 2); as game managers believe that predators are too abundant (or simply observe that they are present in their estate) and they have observed animals and/or nests consumed by predators, then they expect that the effect of predation on small-game species is high.

A "hyperawareness" of risk can emerge because respondents intentionally or unintentionally exaggerate the losses they suffer due to wildlife (Dickman 2010). In this respect, the belief of game managers regarding the negative effect of predators on small-game species and on hunting bags seems to be exaggerated, at least on certain cases. On the one hand, the consumption of small-game species by predators is usually low (e.g., Díaz-Ruíz et al. 2013), and, on the other hand, other sources of mortalities may be more important than predation. For example, in Alaska predator-induced moose (Alces alces) calf winter mortality was proportionally much lower than that attributable to other causes, such as snow depth and temperature (Keech et al. 2011). Similarly, in central Spain, agricultural practices, and not predation, appear to be the main cause of nest failure in red-legged partridge (Casas and Viñuela 2010). In fact, scientific information do not support that predation is the main cause of red-legged partridge low productivity or long-term population decline (Casas and Viñuela 2010, Blanco-Aguiar et al. 2012), nor that predator control is the most efficient technique to manage populations of this game species (Mateo-Moriones et al. 2012, DíazFernández et al. 2013). This hyperawareness, also highlighted by the fact that several game managers considered that hunting would be unfeasible without predator control (Table 2), might be based on traditional prejudice of predators by the Spanish hunter community, as occurred in other areas worldwide (for example, Lindsey et al. 2005). This traditional prejudice arises because deliberate policies to reduce numbers of predators have been typical of the European culture everywhere until the last century (Reynolds and Tapper 1996). In Spain, for example, a governmental agency called "Junta de Extinción de Alimañas" ("Vermin extinction council") promoted and sponsored the control of predators until the 1970s, directly causing the killing of tens of thousands of predators in just a decade (Corbelle-Rico and Rico-Boquete 2008).

We acknowledge that concepts such as population limitation/ regulation, sustainable rates of predation losses, intraguild predation, etc. (Polis and Holt 1992, Sinclair and Pech 1996, Sinclair 2003) are not commonly used in everyday conversation by nonscientists (including managers). However, it was interesting that those concepts appeared not to be intuitively understood by game managers, and thus any loss to predators appeared to be valued as excessive (probably due to the historical prejudice, as stated above). Again, the interplay between ecological factors, such as observations of high numbers of predators, and social factors, such as values regarding predators vs. shooting (White et al. 2009), play an important role driving the behavior of game managers (Fig. 1). In this sense, a stronger effort for better communication between researchers and resource managers has been long recognized as a critical need in environmental science (Groffman et al. 2010). Researchers need to be active and share their ecological knowledge about controversial issues, such as predator-prey relationships and predator control, in understandable ways for game managers. Educational programs could also help to ameliorate the historically hostile attitude towards predators (Marker et al. 2003).

In general, most reasons for negativity among managers towards predators are based on perceived economic costs (for example, Davies and du Toit 2004, Lindsey et al. 2005). Thus, the perception of predators is usually influenced by the economic dependency on the resource of the manager (i.e., the interplay between economic and social factors). For instance, in Czech Republic professional and hobby fish farmers show a more negative attitude towards otters (Lutra lutra) than recreational anglers, whose motivations to fish are not economic but driven by outdoor experience (Vaclavikova et al. 2011). Similarly, in southern Kenya Maasai people who raise livestock for sale have a higher reported likelihood of retaliating against predators compared to those who keep stock only for domestic consumption or traditional reasons (Hazzah et al. 2009). In the present study, we observed that only managers from commercial estates used stronger arguments indicating their belief that hunting would not be possible if predators were not removed, which suggests that their tolerance of predators (or the tolerance of the loss of any game to predators) may be lower than that of managers whose main motivation was not economic. Interestingly, we observed a relationship between the strength of the arguments about the effect of predators on hunting and the intensity of predator control carried out, which suggests that perceptions and economic interests influence management decisions or behavior. 


\section{CONCLUSIONS AND THE WAY FORWARD}

Hunting is an important economic activity in rural areas of central Spain, and there is an interest to develop the economic value of hunting in rural areas (Bernabeu 2000). Therefore, if economic interests increase the negative perception of predators, it is likely that conflicts may increase. On the other hand, hunting estates are home to most of the country's wildlife (since they occupy such a large proportion of the national surface). From this perspective, seeking to isolate predators from hunters and to conserve them in protected areas is inadequate. Therefore, a land-use strategy is required that integrates the needs of both hunting and conservation, through which hunters become custodians rather than adversaries of predators and their prey (Marker et al. 2003). Partly, this is prevented because managers also consider predator control a steward activity; i.e., they consider this keeps some sort of ecological balance, and thus that this represents a service to society at large (see results but also Treves 2009). Indeed, predator control has been proven to be associated with benefits for some biodiversity indicators (Fletcher et al. 2010), although these results are not general in all contexts. In our study area, it has been shown that predator control may be beneficial for other species of conservation concern, such as some ground-nesting steppe birds (Suárez et al. 1993, Estrada et al. 2012). In addition, most partridge losses to predation are caused by anthropophilic common predators (Herranz 2001), such as foxes and magpies, which can be legally controlled. Under this perspective, a global consensus about predator control could be reached among traditionally opposing views of environmentalists and hunters. This would benefit the maintenance of an important socio-economic activity in rural areas while benefiting overall biodiversity conservation, which would give to hunting an additional value that could improve the image of this activity in the wider society. To reach this optimal win-win situation, more work on the perceptions about predators and wildlife at large among managers and conservationists should be developed to look for common ground, and more work about quantifying the economic losses to predation (in comparison with economic investments on predator control) should be developed, as quantification may help influencing perceptions. Beyond that, game managers should stop using illegal and nonselective control methods in order to modify the perception of nonhunters that the use of illegal methods is widespread (Thompson et al. 2009). On the other hand, ecological scientists should boost the ongoing process of evaluation of the selectivity of predator control methods (Muñoz-Igualada et al. 2008, Díaz-Ruíz et al. 2010), should encourage the development of sound experimental research on alternative selective methods that are viewed as effective by managers, and should continue work on the effects of predation on population ecology of red-legged partridge, and other game and nongame prey. Moreover, an effective communication of scientific findings to the general public, and in this particular case to the game managers (particularly those with strong economic interests), should be promoted (Groffman et al. 2010).

In summary, our study shows that predator control for hunting interests is very widespread in central Spain, which reflects the general perception of managers observed in this study that predators (including, frequently, protected ones) are responsible for significant game losses and should be removed. It also shows that the intensity of predator control seems influenced by the perceptions of managers about predators, and this in turn is also associated with the economic interests of the game manager, which also seems to influence the methods used. Thus, our results highlight the important role that both social and economic factors (even stronger than ecological factors) play driving predator control, and therefore the need of incorporating these factors when making decisions to mitigate the human-predator conflict (see also White et al. 2009). We would thus like to call to attention on the importance of combining ecological studies with social and economic sciences (Robinson 2006), as well as the need of involving stakeholders in the conservation process to effectively resolve the conflicts between human activities and protected species (Vaclavikova et al. 2011).

Responses to this article can be read online at: http://www.ecologyandsociety.org/issues/responses. php/5367

\section{Acknowledgments:}

This work was supported by the European Commission under the 7th Framework Programme for Research and Technological Development through project HUNT (212160, FP7-ENV-2007-1), Ministerio de Ciencia y Tecnología (CGL2008-04282/BOS) and the Consejería de Agricultura of Junta de Comunidades de Castilla-La Mancha (JCCM). Additionally, this paper uses partial data from a project funded by the Fundación Fauna y Flora. S. Díaz-Fernández had a predoctoral grant jointly financed by the European Social Fund and by JCCM, in the framework of the Operational Programme PRINCET 2005-2010. M. Delibes-Mateos is currently holding a Juan de la Cierva research contract awarded by the Ministerio de Ciencia e Innovacion and the European Social Fund. We thank all game managers for their collaboration, and ADEMAC and the Asociación de cotos de caza menor Sierra de Alcaraz-Campo de Montiel for facilitating this collaboration with game managers. We thank Dr. Anke Fischer, Dr. Carl Folke, the Subject Editor and two anonymous reviewers for useful comments on the manuscript. 


\section{LITERATURE CITED}

Alonso, M. E., J. A. Pérez, V. R. Gaudioso, C. Diéz, and R. Prieto. 2005. Study of survival, dispersal and home range of autumn-released red-legged partridges (Alectoris rufa). British Poultry Science 6:401-406.

Arroyo, B., M. Delibes-Mateos, S. Díaz-Fernández, and J. Viñuela. 2012. Hunting management in relation to profitability aims: red-legged partridge hunting in central Spain. European Journal of Wildlife Research 58:847-856. http://dx.doi.org/10.1007/s10344-012-0632-4

Baker, S. E., and D. W. Macdonald. 2000. Foxes and foxhunting in Wiltshire: a case study. Journal of Rural Studies 16:185-201. http://dx.doi.org/10.1016/S0743-0167(99)00051-0

Baker, P. J., S. Harris, C. P. J. Robertson, G. Saunders, and P. C. L. White. 2001. Differences in the capture rate of cagetrapped red foxes Vulpes vulpes. Journal of Applied Ecology 38:823-835.

Beja, P., L. Gordinho, L. Reino, F. Loureiro, M. Santos-Reis, and R. Borralho. 2009. Predator abundance in relation to small game management in southern Portugal: conservation implications. European Journal of Wildlife Research 55:227-238. http://dx.doi.org/10.1007/s10344-008-0236-1

Bernabeu, R. L. 2000. Evaluación económica de la caza en Castilla-La Mancha. PhD Thesis. University of Castilla-La Mancha, Spain.

Blanco-Aguiar, J. A., M. Delibes-Mateos, B. Arroyo, P. Ferreras, F. Casas, R. Real, J. M. Vargas, R. Villafuerte, and J. Viñuela. 2012. Is the interaction between rabbit hemorrhagic disease and hyperpredation by raptors a major cause of the red-legged partridge decline in Spain? European Journal of Wildlife Research 58:433-439. http://dx.doi.org/10.1007/ s10344-011-0593-z

Boitani, L. 1995. Ecological and cultural diversities in the evolution of wolf-human relationships. Pages 3-11 in L. N. Carbyn, S. H. Fritts, and D. R. Seip, editors. Ecology and Conservation of Wolves in a Changing World, Canadian Circumpolar Institute, Edmonton, Canada.

Casas, F., and J. Viñuela. 2010. Agricultural practices or game management: Which is the key to improve red-legged partridge nesting success in agricultural landscapes? Environmental Conservation 37:177-186. http://dx.doi. org/10.1017/S0376892910000299

Corbelle-Rico, E. J., and E. Rico-Boquete. 2008. La actividad de las juntas de extinción de animales dañinos en España. Pages 1944-1968 in Proceedings of the IX Congreso de la Asociación de Historia Contemporánea, University of Murcia, Murcia, Spain. [online] URL: http://www.ahistcon. org/docs/murcia/contenido/pdf/11/eduardoj_corbelle_y_eduardo_rico_taller11.pdf
Dar, N. I., R. A. Minhas, Q. Zaman, and M. Linkie. 2009. Predicting the patterns, perceptions and causes of humancarnivore conflict in and around Machiara National Park, Pakistan. Biological Conservation 142:2076-2082. http://dx. doi.org/10.1016/j.biocon.2009.04.003

Davies, H. T., and J. T. du Toit. 2004. Anthropogenic factors affecting wild dog (Lycaon pictus) reintroductions: a case study in Zimbabwe. Oryx 38:1-10. http://dx.doi.org/10.1017/ $\underline{\text { S0030605304000067 }}$

Delibes-Mateos, M., P. Ferreras, and R. Villafuerte. 2008. Rabbit populations and game management: the situation after 15 years of rabbit haemorrhagic disease in central-southern Spain. Biodiversity and Conservation 17:559-574. http://dx. doi.org/10.1007/s10531-007-9272-5

Díaz-Fernández, S., B. Arroyo, F. Casas, M. Martinez-Haro, and J. Viñuela. 2013. Effect of Game Management on Wild Red-Legged Partridge Abundance. PLoS ONE 8(6): e66671. http://dx.doi.org/10.1371/journal.pone.0066671

Díaz-Fernández, S., J. Viñuela, and B. Arroyo. 2012a. Harvest of Red-legged Partridge in Central Spain. The Journal of Wildlife Management 76:1354-1363. http://dx.doi.org/10.1002/ jwmg.391

Díaz-Fernández, S., M. Díaz-Fernández, B. Arroyo, and J. Viñuela. 2012b. Economic consequences of red-legged partridge restocking in private hunting estates. Pages 129 in Proceedings of the International Conference on hunting for sustainability: ecology, economics and society, 27-29 March 2012, Instituto de Investigación en Recursos Cinegéticos, Ciudad Real, Spain.

Díaz-Ruíz, F., J. T. García, L. Perez-Rodríguez, and P. Ferreras. 2010. Experimental evaluation of live cage-traps for black-billed magpies Pica pica management in Spain. European Journal of Wildlife Research 56:239-248. http://dx. doi.org/10.1007/s10344-009-0310-3

Díaz-Ruíz, F., M. Delibes-Mateos, J. L. García-Moreno, J. M. López-Martín, C. Ferreira, and P. Ferreras. 2013. Biogeographical patterns in the diet of an opportunistic predator: the red fox (Vulpes vulpes) in the Iberian Peninsula. Mammal Review 43(1):59-70. http://dx.doi.org/10.1111/ j.1365-2907.2011.00206.x

Dickman, J. A. 2010. Complexities of conflict: the importance of considering social factors for effectively resolving humanwildlife conflict. Animal Conservation 13:458-466. http://dx. doi.org/10.1111/j.1469-1795.2010.00368.x

Duarte, J., M. A. Farfán, J. E. Fa, and J. M. Vargas. 2012. How effective and selective is traditional Red Fox snaring? Galemys 24:1-11. http://dx.doi.org/10.7325/Galemys.2012.A01 http:// dx.doi.org/10.7325/Galemys.2012.A01 
Estrada, A., J. Caro, P. Beja, L. Borrallho, F. Casas, M. Delibes-Mateos, S. Díaz-Fernández, L. Gordinho, L. Reino, J. Viñuela, and B. Arroyo. 2012. Does hunting management affect non-game bird species? A study from Spain and Portugal. Pages 97 in Proceedings of the International Conference on hunting for sustainability: ecology, economics and society, 27-29 March 2012, Instituto de Investigación en Recursos Cinegéticos, Ciudad Real, Spain.

Ferrer, M., and J. J. Negro. 2004. The near extinction of two large European predators: super specialists pay a prize. Conservation Biology 18:344-349. http://dx.doi.org/10.1111/ j.1523-1739.2004.00096.x

Ferreras, P. 2009. Control de depredadores. Pages 104-127 in J. Carranza and M. Sáenz de Buruaga, editors. Manual para la gestión cinegética en los ecosistemas mediterráneos de Andalucía, Junta de Andalucía, Sevilla, Spain.

Fischer, A., and J. Young. 2007. Understanding mental constructs of biodiversity: implications for biodiversity management and conservation. Biological Conservation 136:271-282. http://dx.doi.org/10.1016/j.biocon.2006.11.024

Fletcher, K., N. J. Aebischer, D. Baines, R. Foster, and A. N. Hoodless. 2010. Changes in breeding success and abundance of ground-nesting moorland birds in relation to the experimental deployment of legal predator control. Journal of Applied Ecology 47:263-272. http://dx.doi.org/10.1111/ j.1365-2664.2010.01793.x

Gónzález, L. M., A. Margalida, S. Mañosa, R. Sánchez, J. Oria, J. L. Molina, J. Caldera, A. Aranda, and L. Prada. 2007. Causes and spatio-temporal variations of non-natural mortality in the vulnerable Spanish imperial eagle Aquila adalberti during a recovery period. Oryx 41:495-502. http:// dx.doi.org/10.1017/S0030605307414119

Gortázar, C. 1997. Ecología y patología del zorro (Vulpes vulpes L.) en el valle medio del Ebro. PhD Thesis. Universidad de Zaragoza, Spain.

Groffman, P. M., C. Stylinski, M. C. Nisbet, C. M. Duarte, R. Jordan, A. Burgin, M. A. Previtali, and J. Coloso. 2010. Restarting the conversation: challenges at the interface between ecology and society. Frontiers in Ecology and Environment 8: 284-291. http://dx.doi.org/10.1890/090160

Hazzah, L., M. Borgerhoff Mulder, and L. Frank. 2009. Lions and Warriors: Social factors underlying declining African lion populations and the effect of incentive-based management in Kenya. Biological Conservation 142:2428-2437 http://dx.doi. org/10.1016/j.biocon.2009.06.006

Hemson, G., S. Maclennan, G. Mills, P. Johnson, and D. Macdonald. 2009. Community, lions, livestock and money: a spatial and social analysis of attitudes to wildlife and the conservation value of tourism in a human-carnivore conflict in Botswana. Biological Conservation 142:2718-2725 http:// dx.doi.org/10.1016/j.biocon.2009.06.024

Herranz, J. 2001. Efectos de la depredación y del control de depredadores sobre la caza menor en Castilla-La Mancha. PhD Thesis. Universidad Autónoma de Madrid, Spain.

Heydon, M. J., and J. C. Reynolds. 2000. Fox (Vulpes vulpes) management in three contrasting regions of Britain, in relation to agricultural and sporting interests. Journal of Zoology 251: 237-252. http://dx.doi.org/10.1111/j.1469-7998.2000.tb00607. $\underline{x}$

Kaartinen, S., M. Luoto, and I. Kojola. 2009. Carnivorelivestock conflicts: determinants of wolf (Canis lupus) depredation on sheep farms in Finland. Biodiversity and Conservation 18:3503-3517. http://dx.doi.org/10.1007/ s10531-009-9657-8

Keech, M. A., M. S. Lindberg, R. D. Boertje, P. Valkenburg, B. D. Taras, T. A. Boudreau, and K. B. Beckmen. 2011. Effects of predator treatments, individual traits, and environment on moose survival in Alaska. Journal of Wildlife Management 75:1361-1380. http://dx.doi.org/10.1002/jwmg.188

Kushnir, H., H. Leitner, D. Ikanda, and C. Packer. 2010. Human and ecological risk factors for unprovoked lion attacks on humans in Southeastern Tanzania. Human Dimensions of Wildlife 15:315-331. http://dx.doi.org/10.1080/10871200903510999

Kvale, S. 1996. Interviews: An Introduction to Qualitative Research Interviewing. Sage, London, United Kingdom.

Langley, P. J. W., and D. W. Yalden. 1977. The decline of the rarer carnivores in Great Britain during the nineteenth century. Mammal Review 7:96-116. http://dx.doi.org/10.1111/ j.1365-2907.1977.tb00363.x

Lindsey, P. A., J. T. Du Toit, and M. G. L. Mills. 2005. Attitudes of ranchers towards African wild dogs Lycaon pictus: Conservation implications on private land. Biological Conservation 125:113-121. http://dx.doi.org/10.1016/j. biocon.2005.03.015

Maccoby, E. E., and N. Maccoby. 1954. The interview: A tool of social science. Pages 449-487 in G. Lindzey, editor. Handbook of social psychology, Addison- Wesley, Cambridge, United States.

Macdonald, D. W., and P. J. Johnson. 1996. The impact of sport hunting: a case study. Pages 160-207 in N. Dunstone and V. J. Taylor. The exploitation of mammal populations. Chapman \& Hall, London, United Kingdom. http://dx.doi. org/10.1007/978-94-009-1525-1_11

Macdonald, D., and K. Service. 2007. Hot Topics in Conservation. Blackwell Publishing, Oxford, United Kingdom. 
Marker, L. L., M. G. L. Mills, and D. W. Macdonald. 2003. Factors Influencing Perceptions of Conflict and Tolerance toward Cheetahs on Namibian Farmlands. Conservation Biology 17:1290-1298. http://dx.doi.org/10.1046/ j.1523-1739.2003.02077.x

Márquez, C., J. M. Vargas, R. Villafuerte, and J. E. Fa. 2012. Understanding the propensity of wild predators to illegal poison baiting. Animal Conservation, 16(1):118-129. http:dx. doi.org/10.1111/j.1469-1795.2012.00581.x http://dx.doi.org/10.1111/ j.1469-1795.2012.00581.x

Mateo-Moriones, A., R. Villafuerte, and P. Ferreras. 2012. Does fox control improve red-legged partridge (Alectoris rufa) survival? An experimental study in northern Spain. Animal Biodiversity and Conservation, 35:395-404.

Mayring, P. 2000. Qualitative Content Analysis. Forum Qualitative Sozial- forschung/Forum: Qualitative Social Research, 1 Art.20 [online] URL: http://www.qualitativeresearch.net/index.php/fqs/article/view/1089/2385

Messmer, T. A., M. W. Brunson, D. Reiter, and D. G. Hewitt. 1999. United States public attitudes regarding predators and their management to enhance avian recruitment. Wildlife Society Bulletin 27:75-85

Miller, S. D., J. W. Schoen, J. Faro, and D. R. Klein. 2011. Trends in intensive management in Alaska's Grizzly Bears, 1980-2010. Journal of Wildlife Management 75:1243-1252. http://dx.doi.org/10.1002/jwmg.186

Muñoz-Igualada, J., J. A. Shivik, F. G. Domínguez, J. L. Lara, and L. M. González. 2008. Evaluation of cage-traps and cable restraint devices to capture red foxes in Spain. The Journal of Wildlife Management 72:830-836. http://dx.doi.org/10.2193/2007-198

Oñate, J. J., and B. Peco. 2005. Policy impact on desertification: stakeholders' perception in south Spain. Land Use Policy 22:103-114. http://dx.doi.org/10.1016/j. landusepol.2004.01.002

Polis, G. A., and R. D. Holt. 1992. Intraguild predation: the dynamics of complex trophic interactions. Trends in Ecology \& Evolution 7:151-154. http://dx.doi.org/10.1016/0169-5347 (92)90208-S

Reynolds, J. C., and S. C. Tapper. 1996. Control of mammalian predators in game management and conservation. Mammal Review 26:127-156. http://dx.doi.org/10.1111/j.1365-2907.1996. tb00150.x

Ríos-Saldaña, C. A. 2010. Los Planes Técnicos de Caza de Castilla-La Mancha y su Aplicación en la Gestión y Conservación de las Especies Cinegéticas. PhD Thesis. University of Castilla-La Mancha, Spain.

Robinson J. G. 2006. Conservation biology and real-world conservation. Conservation Biology 20:658-669. http://dx. doi.org/10.1111/j.1523-1739.2006.00469.x
Robinson, H. S., R. B. Wielgus, H. S. Cooley, and S. W. Cooley. 2008. Sink population in carnivore management: Cougar demography and immigration in a hunted population. Ecological Applications 18:1028-1037. http://dx.doi. org/10.1890/07-0352.1

Schüttler, E., R. Rozzi, and K. Jax. 2011. Towards a societal discourse on invasive species management: A case study of public perceptions of mink and beavers in Cape Horn. Journal for Nature Conservation 19:175-184. http://dx.doi. org/10.1016/j.jnc.2010.12.001

Sergio, F., T. Caro, D. Brown, B. Clucas, J. Hunter, J. Ketchum, K. McHugh, and F. Hiraldo. 2008. Top predators as conservation tools: Ecological rationale, assumptions, and efficacy. Annual Review of Ecology, Evolution, and Systematics 39:1-19. http://dx.doi.org/10.1146/annurev. ecolsys.39.110707.173545

Sinclair, A. R. E., and R. P. Pech. 1996. Density dependence, stochasticity, compensation and predator regulation. Oikos 75:164-173. http://dx.doi.org/10.2307/3546240

Sinclair, A. R. E. 2003. Mammal population regulation, keystone processes and ecosystem dynamics. Philosophical Transactions Of The Royal Society Of London Series BBiological Sciences 358:1729-1740. http://dx.doi.org/10.1098/ rstb.2003.1359

Smith, R. K., A. S. Pullin, G. B. Stewart, and W. J. Sutherland. 2010. Effectiveness of predator removal for enhancing bird populations. Conservation Biology 24:820-829. http://dx.doi. org/10.1111/j.1523-1739.2009.01421.x

Suárez, F., M. Yanes, J. Herranz, and J. Manrique. 1993. Nature reserves and the conservation of Iberian shrubsteppe passerines: The paradox of nest predation. Biological Conservation 64:77-81. http://dx.doi.org/10.1016/0006-3207 (93)90385-E

Thirgood, S., S. E. Redpath, I. Newton, and P. Hudson. 2000. Raptors and red grouse: Conservation conflicts and management solutions. Conservation Biology 14:95-104. http://dx.doi.org/10.1046/j.1523-1739.2000.99013.x

Thompson, P. S., A. Amar, D. G. Hoccom, J. Knott, and J. D. Wilson. 2009. Resolving the conflict between driven-grouse shooting and conservation of hen harriers. Journal of Applied Ecology 46:950-954. http://dx.doi.org/10.1111/

\section{j.1365-2664.2009.01687.x}

Tapper, S. 1999. A Question of Balance. Game animals and their role in the British countryside. The Game Conservancy Trust, Fordingbridge, United Kingdom.

Treves, A. 2009. Hunting for large carnivore conservation. Journal of Applied Ecology 46:1350-1356. http://dx.doi. org/10.1111/j.1365-2664.2009.01729.x 
Vaclavikova, M., T. Vaclavik, and V. Kostkan. 2011. Otters vs. fishermen: Stakeholders' perceptions of otter predation and damage compensation in the Czech Republic. Journal for Nature Conservation 19:95-102. http://dx.doi.org/10.1016/j. jnc.2010.07.001

Valkama, J., E. Korpimaki, B. Arroyo, P. Beja, V. Bretagnolle, E. Bro, R. Kenward, S. Mañosa, S. M. Redpath, S. J. Thirgood, and J. Viñuela. 2005. Birds of prey as limiting factors of gamebird populations in Europe: a review. Biological Reviews 80:171-203. http://dx.doi.org/10.1017/S146479310400658X

Villafuerte, R., J. Viñuela, and J. C. Blanco. 1998. Extensive predator persecution caused by population crash in a game species: the case of red kites and rabbits in Spain. Biological Conservation 84:181-188. http://dx.doi.org/10.1016/S0006-3207 (97)00094-3

Virgós, E., and A. Travaini. 2005. Relationship between smallgame hunting and carnivore diversity in central Spain. Biodiversity and Conservation 14:3475-3486. http://dx.doi. org/10.1007/s10531-004-0823-8

Webber, A. D., C. M. Hill, and V. Reynolds. 2007. Assessing the failure of a community-based-human-wildlife conflict mitigation project in Budongo Forest Reserve, Uganda. Oryx 41:177-184. http://dx.doi.org/10.1017/S0030605307001792

White, R. M., A. Fischer, K. Marshall, J. M. J. Travis, T. J. Webb, S. di Falco, S. M. Redpath, and R. van der Wal. 2009. Developing an integrated conceptual framework to understand biodiversity conflicts. Land Use Policy 26:242-253 http://dx. doi.org/10.1016/j.landusepol.2008.03.005

Whitfield, D. P., D. R. A. McLeod, J. Watson, A. H. Fielding, and P. F. Haworth. 2003. The association of grouse moor in Scotland with the illegal use of poisons to control predators. Biological Conservation 114:157-163. http://dx.doi.org/10.1016/ S0006-3207(03)00019-3

Woodroffe, R., S. Thirgood and A. Rabinowitz. 2005. People and wildlife. Conflict or coexistence? Cambridge University Press, Cambridge, United Kingdom. http://dx.doi.org/10.1017/ CBO9780511614774 